\title{
COMPOSITION AND FUNCTIONING OF MICROBIAL COMMUNITIES IN THE DECOMPOSITION OF STRAW CEREALS IN SOD PODZOLIC SOIL
}

\section{O.V. ORLOVA ${ }^{1}$, E.E. ANDRONOV11, N.I. VOROBYOV ${ }^{1}$, A.Yu. KOLODYAZHNII ${ }^{2}$, Yu.P. MOSKALEVSKAYA ${ }^{2}$, N.V. PATYKA ${ }^{2}$, O.V. SVIRIDOVA ${ }^{1}$}

${ }^{1}$ All-Russian Research Institute for Agricultural Microbiology, Federal Agency of Scientific Organizations, 3, sh. Podbel'skogo, St. Petersburg, 196608 Russia, e-mail falenki@hotmail.com, eeandr@gmail.com, vorobyov@arriam.spb.ru, osviridova@newmail.ru;

${ }^{2}$ National Scientific Centre Institute of Agriculture, National Academy of Agricultural Science of Ukraine, 2-B, ul. Mashinistroitelei, pgt Chabany, Kiev Province, 08162 Ukraine, e-mail yulia_moskalevska@mail.ru, o.kolodjazhny@i.ua, n_patyka@mail.ru

Acknowledgements:

Supported by Russian Science Foundation (project № 14-26-00094). Experiments have been carried out on the equipment of ARRIAM Center for genomic technologies, proteomics and cell biotechnology

Received March 30, 2015

\section{Abstract}

Microbial transformation of fresh organic matter in arable soils defines different processes such as the global carbon cycle, food production and impacts on the environment. One of the available ways to improve the content of soil organic matter is the rational use of crop residues, such as straw. A limited use of straw is usually explained by its long decomposition in soil that leads to soil deficiency in mineral nitrogen and accumulation of phytotoxic compounds and phytopathogens. Therefore, the microbial preparations used to accelerate the cereals' straw transformation may be of inrerest. In the model laboratory experiment we studied the effect of rye straw treatment with biopreparates BUGS (based on Bacillus), Barcon (complex cellulosolitic association) and Omug (bio-fertilizer from litter poultry dung) developed in the ARRIAM, depending on the depth of seal (surficial, in a layer of $0-3 \mathrm{~cm}$, in the layer $9-12 \mathrm{~cm}$ ) of straw on the composition and functioning of soil microbial community. It is known that the most available organic compounds are decomposed in the first 2 weeks, so after 2 months we evaluated the effect of preparations and depth of placing straw into the soil on the bacterial community composition in the late stages of decomposition and destruction of difficulty decomposable compounds. During this period the straw decomposition is due generally to k-strategists. There is a perception that their community is more resistant to external influences and will not vary so much as r-strategists responsible for the early stage. After 60 days we determined the abundance of physiological groups of microorganisms, the microbial biomass, content of labile compounds of nitrogen and carbon, as well as respiration. We confirmed poor applicability of conventional microbiological analysis of physiological groups of microorganisms for the purposes of comparing the structure of microbial communities. There was a clear positive impact of straw on the abundance of amylolytic, pedotrofnyh and oligotrophic microorganisms. In this regard, the structure of the microbial community was evaluated by high-throughput sequencing libraries of $16 \mathrm{~S}$ rRNA gene. A positive effect of straw on the number and activity of microorganisms, microbial biomass, labile organic carbon was shown. The tested preparations increased the straw decomposition, and the greatest effect, except Omug, was in a layer of $0-3 \mathrm{~cm}$. Over $80 \%$ of the soil bacterial community was represented by Proteobacteria and Actinobacteria, and the presence of Acidobacteria was lower due to the high fertility of the soil. Adding straw increased proportion of Actinobacteria and Betaproteobaktery compared to control. Actinobacteria were more involved in the decomposition of straw in the 9-12 cm layer, except the treatment with Barcon. It was shown that in case of Barcon and Omug, the biodiversity in the microbial community was higher (the Shannon index was 1.29-1.27 against 1.0-1.16 for control and untreated straw).

Keywords: straw, soil microbial community, humus, microorganisms.

Microbial transformation of fresh organic matter in arable soils is the key factor that defines such processes as the global carbon cycle, food production, and glasshouse effect [1]. One of the available ways to increase the content of soil organic matter is the rational use of crop residues, particularly straw, 150 
thousand tons of which are produced in the Russian Federation annually [2]. The reason for the limited use of this approach is usually explained by the long decomposition of straw in soil which causes soil deficiency in mineral nitrogen and accumulation of phytotoxic compounds and phytopathogens. Therefore, microbial preparations used to accelerate the cereal straw transformation are of the increasing importance [3, 4].

Recently, molecular methods are becoming more common to describe the composition of soil microbial communities, but the issue of the association of biodiversity with the functioning of microbial communities remains open [5, 6]. This is due to a number of reasons including microorganism polyfunctionality, so changes in the microbial community taxonomic composition do not necessarily indicate a change in the chemical properties of the decomposing substrate $[6,7]$. The role and structure of the microbial community responsible for decomposition is poorly understood in relation to the orientation of destructive chains towards the predominance of mineralization or humification $[8,9]$. In particular, no more than $10 \%$ of soil microorganisms are known to or can be cultured in elective nutrient media, the others are a vast resource for studies.

The purpose of this study was to evaluate the effects of straw, biological preparation and the depth of straw embedment on the structure and functioning of the microbial community of soil microorganisms. The most easily accessible straw organic compounds are decomposed within the first 2 weeks, so we evaluated the effect of preparations and the depth of straw embedment in soil on the bacterial community composition after 2 months at the late stages of decomposition when destruction of difficulty decomposable compounds takes place. During this period, straw decomposition is due generally to k-strategists. There is a perception that this community is more resistant to external influences and will not vary so much as in r-strategists responsible for the first stage [10].

Technique. In the model experiment with well-cultivated sod-podzolic soil $\left(\mathrm{C}_{\text {hum }} 4.02 \%, \mathrm{~N}_{\text {total }} 0.316 \%\right.$, $\mathrm{pH}_{\text {salt }} 5.63$, labile $\mathrm{P}_{2} \mathrm{O}_{5}$ of $37 \mathrm{mg} / 100 \mathrm{~g}$, exchangeable $\mathrm{K}$ of $9.6 \mathrm{mg} / 100 \mathrm{~g}$ ), rye straw crushed into pieces of $1-2 \mathrm{~cm}$ was added to plastic pots at $3 \mathrm{~g}$ per kilogram of soil (ash content of $3.4 \%, \mathrm{~N}$ of $0.25 \pm 0.02, \mathrm{C} / \mathrm{N}-195$ ) in three ways (surficially, in the layer of $0-3 \mathrm{~cm}$, and in the layer of $9-12 \mathrm{~cm}$ ). To accelerate decomposition, straw was treated with biopreparations BUGS (based on Bacillus), Barcon (complex cellulosolitic association) and Omug (bio-fertilizer from litter poultry dung) according to the developer recommendations (All-Russian Research Institute of Agricultural Microbiology, St. Petersburg). Analyses were performed at the day 60 .

Agrochemical soil studies were performed using conventional methods [11]. Carbon content in extracts was determined using an Ultraspec spectrophotometer (LKB, Sweden; $\lambda=340 \mathrm{~nm}$ ) [12]. Soil respiration was measured using the Tsvet gas chromatograph (Russia) with katharometer detector and helium as carrier gas.

Active soil microbial biomass was measured by substrate-induced respiration [13] determining the total biomass and fungal biomass (treatment with streptomycin and rifampicin, $16 \mathrm{mg}$ of antibiotic per gram of soil). Microbial biomass nitrogen was analyzed using the rehydration method [14], content of residual straw in the soil was analysed by flotation in $0.5 \mathrm{~N} \mathrm{Na}_{2} \mathrm{SO}_{4}$. The numbers of microflora physiological groups (ammonifying and amylolytic organisms, actinobacteria, cellulosolitic bacteria, pedotrophs, oligotrophs, the total number of bacteria, micromycetes) were counted at planting soil suspension on solid nutrient media. Biodiversity of microbial communities was estimated by Shannon diversity index and Sorensen-Czekanowski similarity coefficient.

The structure of the microbial community at day 60 was evaluated by 
high-throughput sequencing libraries of 16S rRNA gene. DNA was isolated from soil using MoBio (USA) kits, preparation of libraries was performed by PCR with universal primers for 16S rRNA F515 and R806 genes [15]. Sequencing was performed using a GS Junior (Roche, USA) apparatus, sequencing results processing was performed by the QIIME program [16].

Standard statistical methods, graph analysis [17] and principal component analysis were used for further statistical analysis.

Results. Determination of the number of microorganisms in soil layers revealed higher sensitivity to straw adding in micromycetes compared to bacteria (Table 1). In most cases, the number of fungi in the layer with straw increased 1.5-2.0 times. Adding of straw increased the fungi biomass. Thus, our results are consistent with the literature data on the leading role of fungi at the deeper stages of straw decomposition [10]. The depth of straw embedment had greater impact on the number of fungi and bacteria than the type of the biological preparation applied.

Poor applicability of conventional microbiological analysis of physiological microorganism groups for the purposes of comparing the structure of microbial communities was confirmed. There was a clear positive impact of straw on the abundance of amylolytic, oligotrophic, and pedotrophic organisms (see Table 1), while the differences between the variants were insignificant in most cases. A possible reason is that this method registers only growing microorganisms, whereas slow-growing k-strategists prevail at the studied stage of straw decomposition.

Straw decomposition on the day 60 of experiment was no more than 10-40\%, which is consistent with the data of a number of studies [1-3] but contrary to the results which describe $50 \%$ decomposition in 1 month [10]. Biological preparations increased mineralization of straw, and the best results were observed in case of treatment of straw with Barcon. Straw decomposition was greater in a layer of $0-3 \mathrm{~cm}$, except Omug with which straw destruction was most active in the layer of $9-12 \mathrm{~cm}$.

The effect of studied factors on the organic matter fractions characterizing the amount of the most accessible organic compounds (water and saltsoluble carbon), the amount of newly formed ( $\mathrm{C}$ in labile humus) or mobile (C in $\mathrm{NaOH}$ - or pyrophosphate extraction) humus (see Table 1) was observed only in easily accessible fractions.

The growth of microbiological activity after adding straw and biological preparations accelerated straw decomposition but not humus decomposition (see Table 1). Omug contributed to humus preservation in soil which is consistent with the results of our research on the effect of bio-fertilizers on the processes of humification [18]. In case of Omug, complex index of humification $\left(K_{\text {hum. }}\right.$ ) [19] increased with adding straw in the 9-12 cm layer similarly to the degree of straw mineralization.

Different depth of straw embedding and its treatment with preparations changed the structure of soil bacterial communities (Table 2). The main part of bacterial community at phyla level was represented by Proteobacteria and Actinobacteria, and the presence of Acidobacteria was lower due to high soil fertility. Adding straw increased the proportion of Actinobacteria and Betaproteobacteria belonging to k-strategists if compared to control. Surface application of straw did not affect the ratio of alphaproteobacteria families many of which are plant symbionts; changes were observed in case of Barcon only. Straw embedment into the soil affected the structure of this taxon considerably, but we could not reveal the regularities depending on the observed effect of the embedment depth or the preparation; possibly, the changes in the reported cases have occurred under the effect of indirect causes (competition, antagonism, etc.). 
Biological and chemical soil characteristics depending on the depth of straw embedment and its treatment with various biological preparations (day 60, model experiments)

\begin{tabular}{|c|c|c|c|c|c|c|c|c|c|c|c|c|c|}
\hline \multirow{2}{*}{ Parameter } & \multirow{2}{*}{$\mathrm{C}$} & \multicolumn{3}{|c|}{ Untreated straw } & \multicolumn{3}{|c|}{ Straw + BUGS } & \multicolumn{3}{|c|}{ Straw + Barcon } & \multicolumn{3}{|c|}{ Straw + Omug } \\
\hline & & $\mathrm{S}$ & $0-3 \mathrm{~cm}$ & $9-12 \mathrm{~cm}$ & $\mathrm{~S}$ & $0-3$ & $9-12$ & $\mathrm{~S}$ & $0-3$ & $9-12$ & $\mathrm{~S}$ & $0-3$ & $9-12$ \\
\hline \multicolumn{14}{|c|}{ Microbiological properties } \\
\hline Bacteria in $0-4 \mathrm{~cm}, \times 10^{6} \mathrm{CFU} / \mathrm{g}$ & $4 \pm 0.7$ & $2 \pm 0.6$ & $5 \pm 0.7$ & $5 \pm 0.6$ & $6 \pm 0.4$ & $4 \pm 0.4$ & $4 \pm 0.4$ & $7 \pm 0.7$ & $6 \pm 0.2$ & $3 \pm 0.4$ & $4 \pm 0.6$ & $4 \pm 0.3$ & $2 \pm 0.2$ \\
\hline Bacteria in $8-12 \mathrm{~cm}, \times 10^{6} \mathrm{CFU} / \mathrm{g}$ & $2 \pm 0.2$ & $2 \pm 0.2$ & $2 \pm 0.4$ & $6 \pm 0.6$ & $2 \pm 0.3$ & $5 \pm 0.4$ & $6 \pm 0.9$ & $5 \pm 0.6$ & $3 \pm 0.4$ & $6 \pm 0.4$ & $4 \pm 0.4$ & $3 \pm 0.4$ & $7 \pm 0.6$ \\
\hline Fungi in $0-4 \mathrm{~cm}, \times 10^{3} \mathrm{CFU} / \mathrm{g}$ & $31 \pm 2.8$ & $28 \pm 1.4$ & $30 \pm 3.7$ & $7 \pm 0.8$ & $22 \pm 2.9$ & $41 \pm 2.1$ & $15 \pm 1.4$ & $25 \pm 2.1$ & $43 \pm 3.7$ & $12 \pm 1.0$ & $21 \pm 2.8$ & $11 \pm 1.6$ & $6 \pm 0.8$ \\
\hline Fungi in $8-12 \mathrm{~cm}, \times 10^{3} \mathrm{CFU} / \mathrm{g}$ & $20 \pm 1.6$ & $21 \pm 3.7$ & $21 \pm 2.8$ & $24 \pm 1.6$ & $12 \pm 2.1$ & $21 \pm 2.8$ & $38 \pm 4.2$ & $15 \pm 2.4$ & $18 \pm 1.6$ & $25 \pm 1.7$ & $12 \pm 1.4$ & $12 \pm 2.1$ & $15 \pm 1.4$ \\
\hline Ammonifiers, $\times 10^{6} \mathrm{CFU} / \mathrm{g}$ & $12 \pm 0.8$ & $16 \pm 2.4$ & $16 \pm 0.3$ & $13 \pm 0.8$ & $15 \pm 0.9$ & $17 \pm 1.0$ & $18 \pm 2.2$ & $19 \pm 2.0$ & $14 \pm 0.5$ & $14 \pm 1.0$ & $10 \pm 0.8$ & $16 \pm 1.4$ & $16 \pm 1.4$ \\
\hline Amylolytic organisms, $\times 10^{6} \mathrm{C}$ & $9 \pm 0.6$ & $13 \pm 1.3$ & $14 \pm 1.4$ & $14 \pm 1.1$ & $13 \pm 1.2$ & $11 \pm 1.4$ & $14 \pm 1.3$ & $16 \pm 0.2$ & $13 \pm 1.5$ & $14 \pm 1.6$ & $10 \pm 0.3$ & $14 \pm 1.7$ & $13 \pm 0.6$ \\
\hline $\mathrm{ns}, \times 10^{6} \mathrm{CFU} / \mathrm{g}$ & $6 \pm 0.6$ & $9 \pm 1.1$ & $7 \pm 1.0$ & $10 \pm 0.7$ & $5 \pm 0.4$ & $6 \pm 0.8$ & $6 \pm 0.2$ & $9 \pm 0.8$ & $9 \pm 1.0$ & $9 \pm 0.9$ & $6 \pm 0.6$ & $9 \pm 1.3$ & $7 \pm 0.8$ \\
\hline Pedotrophs, $\times 10^{6} \mathrm{CFU} / \mathrm{g}$ & $6 \pm 0.8$ & $11 \pm 1.1$ & $11 \pm 1.2$ & $10 \pm 1.5$ & $8 \pm 0.7$ & $7 \pm 0.7$ & $8 \pm 0.3$ & $8 \pm 1.0$ & $10 \pm 1.1$ & $11 \pm 1.4$ & $8 \pm 0.6$ & $10 \pm 1.1$ & $11 \pm 1.5$ \\
\hline Cellulosolitic organisms, $\times 10^{3} \mathrm{CFU} / \mathrm{g}$ & $16 \pm 2.0$ & $41 \pm 8.0$ & $66 \pm 8.0$ & $62 \pm 14.0$ & $74 \pm 14.0$ & $168 \pm 8.0$ & $123 \pm 14.0$ & $263 \pm 21.0$ & $127 \pm 16.0$ & $99 \pm 14.0$ & $145 \pm 14.0$ & $113 \pm 8.0$ & $150 \pm 21.0$ \\
\hline $6 \mathrm{CFU} / \mathrm{g}$ & $1.6 \pm 0.20$ & $1.3 \pm 0.20$ & $1.3 \pm 0.20$ & $3.0 \pm 0.60$ & $1.5 \pm 0.30$ & $2.4 \pm 0.40$ & $1.5 \pm 0.30$ & $2.1 \pm 0.60$ & $1.1 \pm 0.20$ & $1.6 \pm 0.30$ & $1.5 \pm 0.20$ & $1.4 \pm 0.20$ & $1.3 \pm 0.30$ \\
\hline $\mathrm{CO}^{2} \mathrm{C}, \mathrm{mg} /(\mathrm{kg} \cdot$ & $9 \pm 0.1$ & $13 \pm 0.8$ & $18 \pm 1.6$ & $14 \pm 0.8$ & $22 \pm 6.2$ & $21 \pm 0.7$ & $22 \pm 1.6$ & $36 \pm 5.7$ & $21 \pm 1.9$ & $15 \pm 3.2$ & $28 \pm 3.5$ & $15 \pm 2.8$ & $12 \pm 1.7$ \\
\hline $\mathrm{hg} / \mathrm{kg}$ & $571 \pm 60$ & $700 \pm 40$ & $697 \pm 52$ & $807 \pm 39$ & $728 \pm 22$ & $749 \pm 101.0$ & $756 \pm 120.0$ & $547 \pm 73$ & $669 \pm 86$ & $603 \pm 72$ & $448 \pm 60$ & $631 \pm 88$ & $652 \pm 104.0$ \\
\hline Fungi $b$ & $81 \pm 7$ & $122 \pm 15$ & $112 \pm 20$ & $111 \pm 10$ & $143 \pm 12$ & $223 \pm 41$ & $87 \pm 14.0$ & $77 \pm 35.0$ & $106 \pm 32$ & $102 \pm 16$ & $109 \pm 11$ & $114 \pm 16$ & $83 \pm 17.0$ \\
\hline Biomass & $44 \pm 0$ & $47 \pm 3.0$ & $53 \pm 4.2$ & $53 \pm 4.9$ & $50 \pm 2.9$ & $43 \pm 2.7$ & $46 \pm 3.0$ & $39 \pm 2.5$ & $46 \pm 2.7$ & $42 \pm 5.6$ & $35 \pm 0.1$ & $41 \pm 2.7$ & $49 \pm 0.5$ \\
\hline Total biomass $\mathrm{C}, \mathrm{mg} / \mathrm{kg}$ & $834 \pm 123$ & $963 \pm 43$ & $1016 \pm 115$ & $1017 \pm 63$ & $1034 \pm 115$ & $1039 \pm 73$ & $847 \pm 63$ & $749 \pm 54$ & $961 \pm 76$ & $947 \pm 47$ & $850 \pm 54$ & $901 \pm 70$ & $988 \pm 82$ \\
\hline \multicolumn{14}{|c|}{$\begin{array}{l}\text { Agrochemical properties } \\
\text { Agral }\end{array}$} \\
\hline $\mathrm{NH}_{4} \mathrm{I}$ & $0.7 \pm 0.10$ & $0.7 \pm 0.10$ & $0.7 \pm 0.10$ & $0.7 \pm 0.10$ & $0.7 \pm 0.10$ & $1.4 \pm 0.10$ & $2.1 \pm 0.10$ & $1.4 \pm 0.10$ & $2.1 \pm 0.10$ & $2.2 \pm 0.10$ & $2.1 \pm 0.10$ & $2.1 \pm 0.10$ & $2.2 \pm 0.10$ \\
\hline & , & 0 & $20+00$ & $17 \pm 1.7$ & $23 \pm 0.1$ & $21 \pm 0.1$ & $20 \pm 0.1$ & $23 \pm 0.1$ & $21 \pm 0.1$ & $20 \pm 1.5$ & $21 \pm 0.8$ & $20 \pm 0.1$ & $19 \pm 0.1$ \\
\hline Water soluble $\mathrm{C}, \mathrm{mg} / \mathrm{kg}$ & $131 \pm 7$ & $132 \pm 30$ & $123 \pm 11$ & $155 \pm 13$ & $174 \pm 26$ & $138 \pm 25$ & $133 \pm 29$ & $133 \pm 26$ & $145 \pm 33$ & $140 \pm 9$ & $168 \pm 27$ & $182 \pm 21$ & $157 \pm 22$ \\
\hline Salt soluble $\mathrm{C}, \mathrm{mg} / \mathrm{kg}$ & $116 \pm 12$ & $113 \pm 8$ & $109 \pm 9$ & $94 \pm 16.0$ & $106 \pm 16$ & $108 \pm 13$ & $109 \pm 14$ & $130 \pm 22$ & $107 \pm 12$ & $109 \pm 8$ & $128 \pm 14$ & $131 \pm 19$ & $116 \pm 11$ \\
\hline Labile & $0.8 \pm 0.10$ & $0.8 \pm 0.05$ & $0.8 \pm 0.01$ & $0.8 \pm 0.05$ & $0.8 \pm 0.02$ & $0.7 \pm 0.10$ & $0.9 \pm 0.10$ & $0.9 \pm 0.01$ & $0.9 \pm 0.10$ & $0.7 \pm 0.01$ & $0.9 \pm 0.10$ & $0.9 \pm 0.10$ & $0.9 \pm 0.10$ \\
\hline Hume & $3.78 \pm 0.050$ & $3.95 \pm 0.080$ & $3.83 \pm 0.040$ & $3.81 \pm 0.140$ & $3.89 \pm 0.050$ & $3.85 \pm 0.070$ & $3.85 \pm 0.040$ & $3.89 \pm 0.040$ & $3.84 \pm 0.030$ & $3.89 \pm 0.080$ & $3.82 \pm 0.040$ & $3.93 \pm 0.050$ & $4.01 \pm 0.050$ \\
\hline Residual straw, mg/100 g & 0 & $262 \pm 15$ & $186 \pm 26$ & $174 \pm 76$ & $216 \pm 98$ & $262 \pm 41$ & $217 \pm 22$ & $250 \pm 62$ & $242 \pm 38$ & $296 \pm 25$ & $247 \pm 83$ & $233 \pm 85$ & $260 \pm 90$ \\
\hline $100 \mathrm{~g}$ & $58 \pm 9.5$ & $53 \pm 6.7$ & $48 \pm 3.6$ & $48 \pm 6.2$ & $61 \pm 12.1$ & $51 \pm 12.0$ & $46 \pm 4.2$ & $51 \pm 6.1$ & $45 \pm 7.0$ & $69 \pm 7.6$ & $56 \pm 16.0$ & $56 \pm 3.5$ & $85 \pm 2.8$ \\
\hline $\mathrm{K}, \mathrm{mg} / 100 \mathrm{~g}$ & $9 \pm 1.2$ & $13 \pm 1.4$ & $8 \pm 1.2$ & $10 \pm 1.0$ & $12 \pm 0.5$ & $10 \pm 1.4$ & $9 \pm 1.1$ & $10 \pm 1.5$ & $11 \pm 1.7$ & $11 \pm 0.4$ & $9 \pm 1.5$ & $9 \pm 0.0$ & $9 \pm 0.5$ \\
\hline $\mathrm{pH}_{\text {salt }}$ & $5.6 \pm 0.02$ & $5.8 \pm 0.02$ & $5.8 \pm 0.01$ & $5.9 \pm 0.05$ & $5.9 \pm 0.02$ & $5.9 \pm 0.05$ & $5.9 \pm 0.07$ & $5.8 \pm 0.04$ & $5.8 \pm 0.02$ & $5.8 \pm 0.03$ & $5.9 \pm 0.01$ & $5.8 \pm 0.10$ & $5.9 \pm 0.03$ \\
\hline Residual strawa, $\mathrm{mg} / 100 \mathrm{~g}$ & 0 & $193 \pm 72$ & $156 \pm 18$ & $155 \pm 36$ & $161 \pm 40$ & $108 \pm 31$ & $126 \pm 34$ & $145 \pm 45$ & $81 \pm 45.0$ & $95 \pm 53.0$ & $193 \pm 48$ & $178 \pm 20$ & $94 \pm 56.0$ \\
\hline $\mathrm{K}_{\mathrm{hum}}^{\mathrm{b}}$ & 3.50 & 3.67 & 2.87 & 2.34 & 3.24 & 2.90 & 3.11 & 3.22 & 3.21 & 3.66 & 2.53 & 3.04 & 3.36 \\
\hline
\end{tabular}

No t e. C - control, S - surface application; a - data for the day 90 of experiment, $\mathrm{b}-$ complex humufica
tion «Methods» (see Fig. 3 as well). Mean and confidence intervals are given at a significance level of $\mathrm{P}=0.05$. 
2. Composition of soil bacterial community (\%) depending on the depth of straw embedment and its treatment with various biological preparations (day 60, model experiments)

\begin{tabular}{|c|c|c|c|c|c|c|c|c|c|c|c|c|c|}
\hline \multirow{2}{*}{ Taxon } & \multirow{2}{*}{$\mathrm{C}$} & \multicolumn{3}{|c|}{ No treatment } & \multicolumn{3}{|c|}{ BUGS } & \multicolumn{3}{|c|}{ Barcon } & \multicolumn{3}{|c|}{ Omug } \\
\hline & & $\mathrm{S}$ & 1 & 2 & $\mathrm{~S}$ & 1 & 2 & $\mathrm{~S}$ & 1 & 2 & $\mathrm{~S}$ & 1 & 2 \\
\hline Archaea & 0.7 & 0.9 & 0.9 & 0.7 & 0.9 & 0.3 & 0.9 & 1.8 & 0.9 & 0.7 & 0.6 & 1.6 & 1.0 \\
\hline Acidobacteria & 2.6 & 2.4 & 3.6 & 2.4 & 2.4 & 1.6 & 2.5 & 4.0 & 2.6 & 2.6 & 1.7 & 3.5 & 4.8 \\
\hline Actinobacteria & 15.6 & 19.3 & 17.5 & 21.9 & 17.9 & 14.8 & 19.3 & 26.7 & 18.4 & 18.8 & 14.3 & 22.0 & 27.2 \\
\hline Bacteroidetes & 0.2 & 0.2 & 0.4 & 0.5 & 2.0 & 0.6 & 0.4 & 0.4 & 5.7 & 0.4 & 0.1 & 0.5 & 0.7 \\
\hline Chloroflexi & 2.2 & 2.0 & 2.5 & 2.8 & 2.9 & 2.2 & 3.1 & 5.1 & 2.6 & 2.9 & 1.9 & 3.2 & 4.6 \\
\hline Firmicutes & 2.3 & 2.6 & 2.6 & 2.4 & 2.2 & 2.0 & 2.6 & 2.8 & 3.2 & 3.1 & 1.7 & 4.0 & 4.4 \\
\hline Gemmatimonadetes & 2.3 & 2.6 & 2.6 & 2.4 & 2.2 & 2.0 & 2.6 & 2.8 & 3.2 & 3.1 & 1.7 & 4.0 & 4.4 \\
\hline Planctomycetacia & 0.8 & 0.9 & 1.3 & 1.8 & 0.8 & 0.6 & 1.0 & 1.5 & 1.4 & 0.7 & 0.7 & 1.6 & 1.9 \\
\hline Alphaproteobacteria & 4.5 & 4.5 & 4.5 & 3.9 & 5.8 & 3.9 & 4.2 & 4.7 & 10.5 & 3.6 & 4.1 & 4.5 & 6.4 \\
\hline Betaproteobacteria & 2.7 & 2.8 & 3.0 & 2.6 & 3.7 & 8.2 & 3.4 & 4.3 & 3.3 & 1.7 & 2.1 & 4.6 & 4.3 \\
\hline Deltaproteobacteria & 2.2 & 2.4 & 2.6 & 2.2 & 2.5 & 1.7 & 2.4 & 4.6 & 2.2 & 2.3 & 1.4 & 3.8 & 4.4 \\
\hline Gammaproteobacteria & 62.3 & 56.8 & 56.7 & 53.5 & 52.4 & 59.1 & 52.0 & 36.4 & 44.2 & 59.3 & 68.1 & 45.9 & 34.0 \\
\hline Other & 1.6 & 2.6 & 1.8 & 2.9 & 4.3 & 3.0 & 5.6 & 4.9 & 1.8 & 0.8 & 1.6 & 0.8 & 1.9 \\
\hline
\end{tabular}

N o t e. C - control, S - surface application; 1 and $2-$ soil layers of $0-3$ and $9-12 \mathrm{~cm}$, respectively. For description of preparations, please see section «Methods».

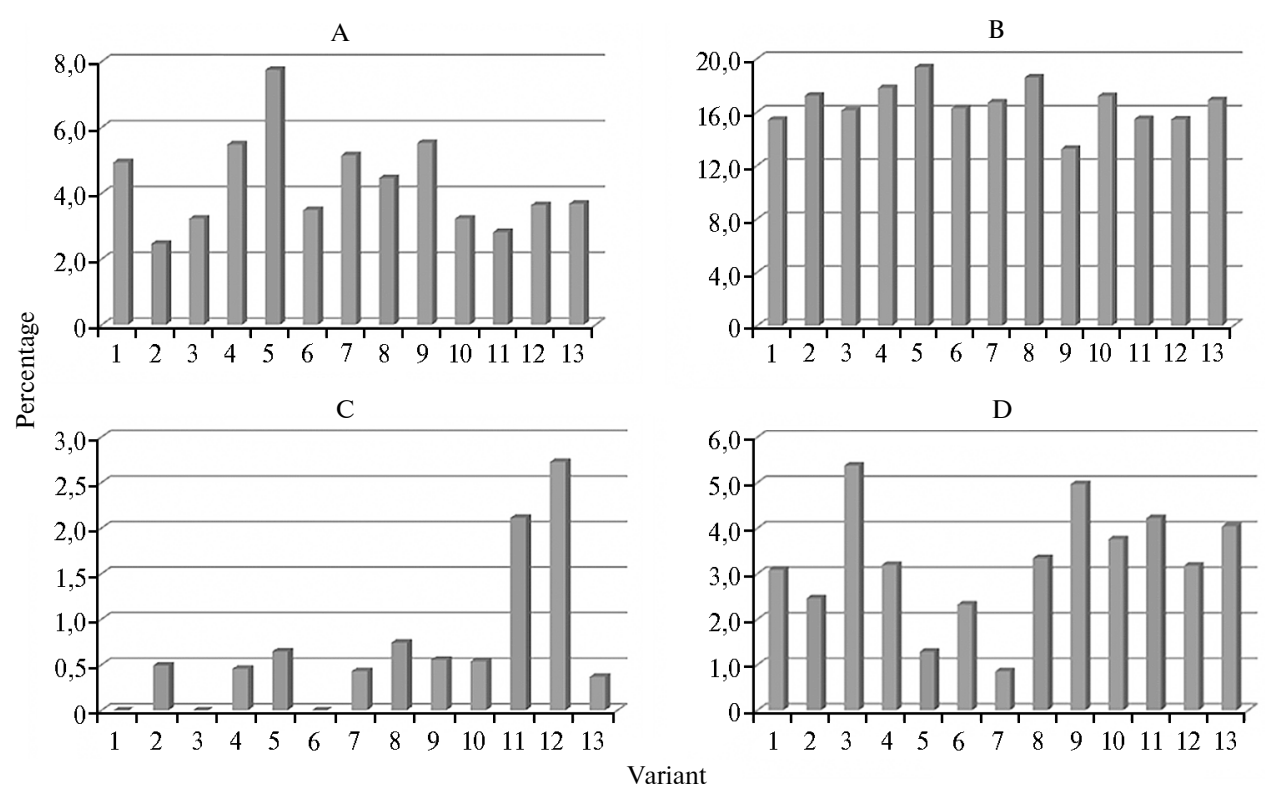

Fig. 1. Representation of Actinobacteria families in the soil depending on the depth of straw embedment and its treatment with different biological preparations: A - Micrococcaceae, B - Gaiellaceae, C - Nocardiaceae, D-Pseudonocardiaceae; 1 - control; 2, 3, 4 - no treatment (surface application and embedment in the layer of $0-3$ and 9-12 cm); 5, 6, $7-$ BUGS treatment (surface application and embedment in the layer of $0-3$ and $9-12 \mathrm{~cm}$ ); 8, 9, $10-$ Barkon treatment (surface application and embedment in the layer of $0-3$ and $9-12 \mathrm{~cm}$ ); 11, 12, 13 - Omug treatment (surface application and embedment in the layer of 0-3 and 9-12 cm) (day 60, model experiments). For description of preparations, please see section «Methods».

Treatment of straw with Omug and Barkon increased the proportion of Actinobacteria playing an important role in destruction of recalcitrant substrates as compared with the case of no treatment. Actinobacteria participation in decomposition was intensified when straw was embedded in the layer of 9-12 cm, with the exception of Barcon (similar to the data of the dominance of bacterial communities in decomposition of embedded plant residues) [20]. Adding of straw and preparations had low effect on Actinobacteria families such as Solirubrobacteraceae and Gaiellaceae, while Micrococcaceae, Nocardioidacea, and Pseudonocardiaceae appeared to be more sensitive to the factors studied (Fig. 1) which reveals the effect of both preparations and of the depth of straw embedment. The greatest differences in the structure of Actinobacteria were ob- 
served between the cases of BUGS and Omug, and the effect of the depth of straw embedment in cases of Barcon and Omug were opposite often.

Firmicutes play an important role in decomposition of fresh organic matter. In case of BUGS, the proportion of Firmicutes was actually 2 times greater which is seemingly understandable, since the product is based on Bacillus. However, the number of Lactobacillaceae increased sharply (increase up to $40 \%$ compared with 5-8\% in untreated straw and in case of Omug, and with $19 \%$ for Barcon), and the number of the Bacillaceae family members was low.

The highest biodiversity of the samples was observed under treatment with Barcon and Omug, when Shannon index was 1.29-1.27 compared to 1.0-1.16 for control and untreated straw. The raise in the microbiome taxonomic diversity is reflected in the increase of its metabolic activity and complexity of trophic links between different physiological groups of microorganisms which is consistent with the strengthening of humification processes (increases in humus content, water-soluble carbon and labile humus).

Analysis of bacterial community similarities using the principal component method with grouping according to straw treatment preparations for components 1 and 2 demonstrated no clear intervariant differences (Fig. 2, A), in case of components 1 and 3 differences between BUGS and Omug were observed. Analysis of grouped data on the depth of straw embedment (see Fig. 2, B) demonstrated insignificant differences, although this factor had strong effect on the microorganism number and activity. Probably, the reasons are quite a late stage of decomposition when the differences between the k-strategists communities are not that evident $[7,10]$, and the more complete structure of the community registered by molecular methods.

Sorensen-Czekanowski similarity coefficients for bacterial communities in the layer of $0-3 \mathrm{~cm}$ (maximum straw decomposition) were the highest ones $(0.72-0.78)$. It means that the most efficient straw decomposing microbial communities have similar composition, and the effect of preparations was low. BUGS was often different from other preparations in the effect on the community structure forming the less similar microbial complexes, particularly in cases of surface application (coefficients ranged from 0.58 to 0.63 ).

It should be noted that many of the parameters describing microbiological (soil respiration, $\mathrm{C}$ and $\mathrm{N}$ content in microbial biomass) and agrochemical (e.g., labile organic carbon and mineral nitrogen content) soil properties change when straw is added (see Table 1), but it is almost impossible to discover clear patterns and to evaluate the effect of the preparation or of the embedment depth without mathematical analysis methods.

The use of graph analysis [15] to assess the microbocenosis functioning reveals the similarities and differences depending on the depth of straw embedment (Fig. 3). The general features are presented by the negative relationship between the amount of residual straw and the nitrogen content in the soil. The amount of immobilized nitrogen in microbial biomass in cases of straw embedment into the soil is closely related to nitrate content. New formation of humus ( $\mathrm{C}$ of labile humus) is associated with microbial biomass which explains the increase in humus content under surface straw application when organic substances enter the soil dissolved. Complex humification index $\left(\mathrm{K}_{\text {hum. }}\right.$.) is related to soil microbiological properties, in particular to mineralization and oligotrophic coefficients which reflects the microbial community structure.

In case of surface application, at the day 60 , straw is the main source of many mobile organic matter pools but as it is decomposed slower, oligotrophic organisms are associated with it. The most active straw decomposition takes place in the upper layer $(0-3 \mathrm{~cm})$ as evidenced by its association with cellulolytic 

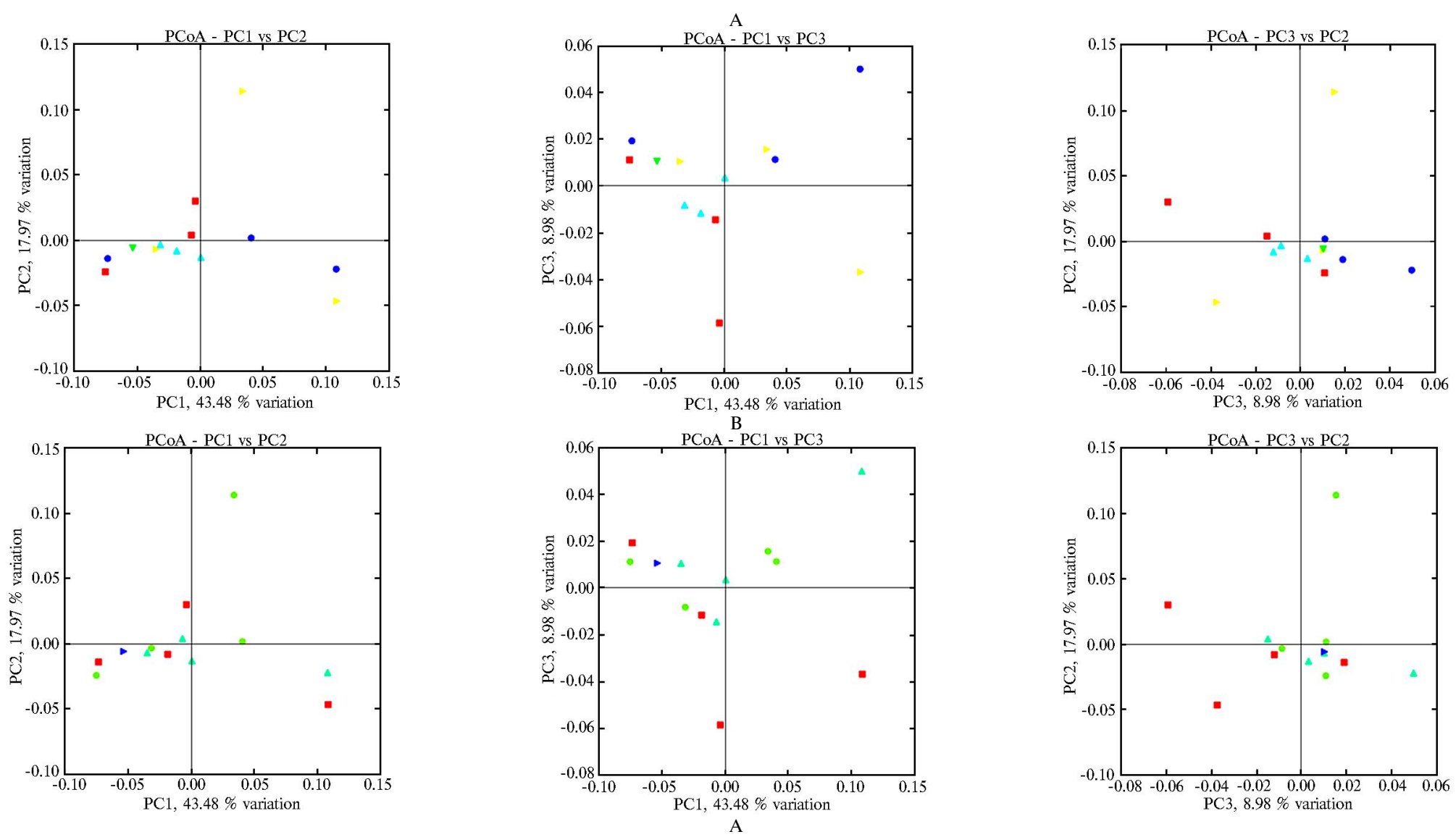

Fig. 2. Analysis of bacterial community similarities using the principal component method with grouping according to straw treatment preparations (A; $\nabla$ control, $\Delta$ straw without treatment; $\square$ BUGS, ○ Barkon, ○ Omug) and embedment depth (B; $\triangleright$ control, $\square$ surficially, $\Delta 0-3 \mathrm{~cm}, \circ 9-12 \mathrm{~cm})$ (model experiments). 


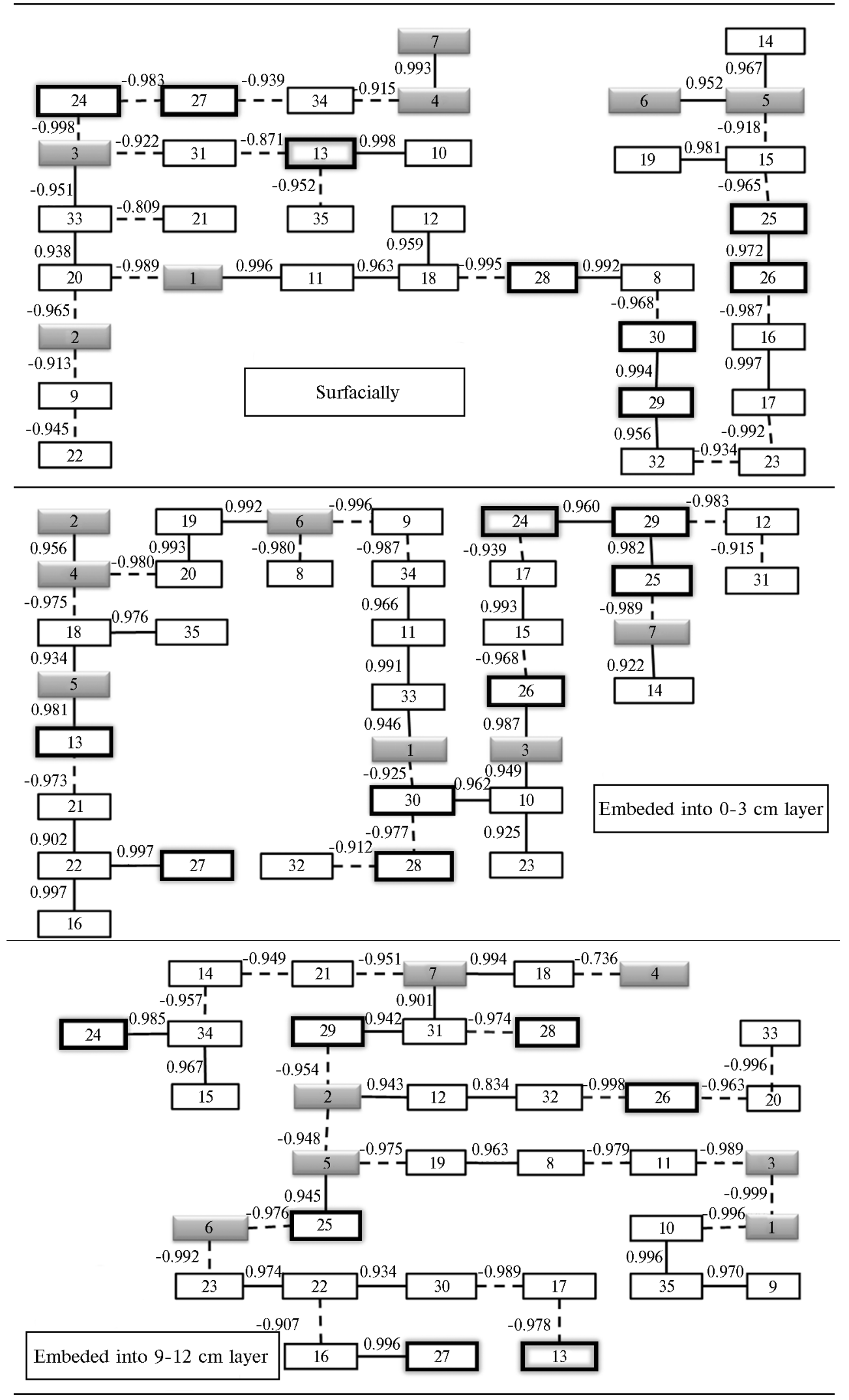

Fig. 3. Graphs of the maximum correlations of the soil and soil microbial community condition indicators depending on the depth of straw embedment and treatment with various biological prepara- 
tions (gray squares are microorganism number, squares outlined with thick frames are C pools): 1 number of ammonifiers, 2 - number of amylolytic organisms, 3 - number of oligotrophs, 4 number of pedotrophs, 5 - number of cellulosolitic bacteria, $6-$ number of actinomycetes, $7-$ number of micromycetes; 8 - mineralization coefficient, 9 - pedotrophic coefficient, 10 - oligotrophic coefficient, 11 - coefficient of organic matter transformation; 12 - humidity; 13 - residual straw content; 14 - soil respiration; 15 - microbial biomass $\mathrm{C}$ (rehydration method); 16 - microbial biomass N; 17 - active biomass $\mathrm{C}$ («bacteria + fungi» sum); 18 - proportion of active biomass of total biomass, \%; 19 - active fungi biomass; 20 - proportion of active fungi biomass of total biomass, $\%$; 21 - total soil nitrogen, 22 - nitrate nitrogen, 23 - ammonium nitrogen; 24 water extract C, $25-\mathrm{K}_{2} \mathrm{SO}_{4}$ extract $\mathrm{C}, 26$ - labile humus $\mathrm{C}$ (neutral pyrophosphate extract), 27 alkaline pyrophosphate extract $\mathrm{C}, 28-0.1 \mathrm{~N} \mathrm{NaOH}$ extract $\mathrm{C}, 29-$ humus $\mathrm{C} ; 30-$ complex humification index; 31 - labile phosphorus, $32-$ labile potassium; $33-\mathrm{pH} ; 34-$ plant yield (obtained in the second period, data not shown); 35 - nitrogen removal by plants (see p. 34).

organisms and by its role in the nitrogen cycle. Depending on the depth of straw embedment, the main contribution to mineralization processes $\left(\mathrm{CO}_{2}\right.$ output $)$ is made by different groups of microorganisms.

Thus, the analysis of the effect of rye straw treatment with biological preparations BUGS, Barcon, and Omug on the composition and functioning of soil microbial community has shown that in its strength the biological preparation effect was comparable with the effect of the straw embedment depth. However, related to the microbiome functioning, and hence to soil properties, the above was not always clearly seen. Here, a possibility of various microbiome taxonomic composition along with the similar results which are due to the multifunctional nature of microorganisms, is confirmed. Under the use of preparations, $60-70 \%$ of straw is decomposed within 90 days compared to $30-50 \%$ in cases of no treatment. The most efficient straw decomposition was observed in the $0-3 \mathrm{~cm}$ layer, except for the cases of treatment with Omug (better in the layer of 9-12 cm), the least efficient decomposition took place when straw was added superficially. Straw decomposition by BUGS and Barcon biological preparations was more efficient than in case of Omug, but the effect of the latter on soil humus was more favorable, as the content of newly formed and total humus increased. Adding of straw increased the proportion of actinobacteria and betaproteobacteria versus control. Actinobacteria are in a greater extent involved in the decomposition of straw embedded in the layer of the 9-12 cm depth (treatment with Barcon was an exception). In case of Barcon and Omug, the microbial community biodiversity was higher (Shannon index of $1.29-1.27$ versus $1.0-1.16$ in control and untreated straw).

\section{R E F E R E N C E S}

1. B a ld o c k J.A. Composition and cycling of organic carbon in soil. In: Nutrient sycling in terrestrial ecosystems. P. Marschner, Z. Rengel (eds.). Springer Berlin Heidelberg, 2007 (doi: 10.1007/978-3-540-68027-7_1).

2. Verzili n V.V., Korzhov S.I., Pridvorev N.I. Biologiya pochv srednerusskogo Chernozem'ya (diagnostika i puti resheniya): monografiya [Biology of soils of Middle Russian Chernoze'e - diagnostics and solutions: a monograph]. Voronezh, 2005.

3. She rsh neva O. M., Taras ov S. A. Vestnik Kurskoi gosudarstvennoi sel'skokhozyaistvennoi akademii, 2014, 6: 41-45.

4. Shcherbakov A.V., Rusakova I.V., Orlova O.V., Vorobyov N.I., Sviridova O.V., S h cherbakova E.N., C he botar V.K. Sel'skokhozyaistvennaya biologiya [Agricultural Biology], 2014, 1: 54-62 (doi: 10.15389/agrobiology.2014.1.54eng).

5. Nannipieri P., Ascher J., Ceccherini M.T., Landi L., Pietramellara G., R e ne 11 a G. Microbial diversity and soil functions. European Journal of Soil Science, 2003, 54(4): 655-670 (doi: 10.1046/j.1351-0754.2003.0556.x).

6. Marschner P., Kandeler E., Marchner B. Structure and function of the soil microbial community in a long-term fertilizer experiment. Soil Biol. Biochem., 2003, 35(3): 453461 (doi: 10.1016/S0038-0717(02)00297-3). 
7. Baumann K., Marschner P., S mernik R.J., B aldok J.A. Residue chemistry and microbial community structure during decomposition of eucalypt, wheat and vetch residues. Soil Biol. Biochem., 2009, 41(9): 1966-1975 (doi: 10.1016/j.soilbio.2009.06.022).

8. Be nding G.D., Turne r M.K., J o nes J.E. Interactions between crop residue and soil organic matter quality and the functional diversity of soil microbial communities. Soil Biol. Biochem., 2002, 34(8): 1073-1082 (doi: 10.1016/S0038-0717(02)00040-8).

9. Coppens F., Garnier P., De Gryze S., Merckx R., Recous S. Soil moisture, carbon and nitrogen dynamics following incorporation and surface application of labelled crop residues in soil columns. European Journal of Soil Science, 2006, 57(6): 894-905 (doi: 10.1111/j.1365-2389.2006.00783.x).

10. Nicolardot B., B ouziri L., B astian F., Ranjard L. A microcosm experiment to evaluate the influence of location and quality of plant residues on residue decomposition and genetic structure of soil microbial communities. Soil Biol. Biochem., 2007, 39(7): 1631-1644 (doi:10.1016/j.soilbio.2007.01.012).

11. Agrokhimicheskie metody issledovaniya pochv /Pod redaktsiei A.V. Sokolova [Agrochemical methods in soil research. A.V. Sokolov (ed.)]. Moscow, 1975.

12. Pa nik ov N.S., G o rbe n k o A.Yu., S ve tlov S.V. Sposob opredeleniya summarnogo soderzhaniya vodorastvorimykh organicheskikh veshchestv v pochve. A.s. № 3949440/30-15. Opubl. 1987. Byul. № 23 [A method for estimation of the total content of water-soluble organic substances in soil. A.C. № 3949440/30-15. Publ. 1987. Bul. № 23].

13. West A.W., Sparling G.P. Modification to the substrate-induced respiration method to permit measurement of microbial biomass in soils of different water contents. J. Microbiol. Meth., 1986, 5: 177-189 (doi: 10.1016/0167-7012(86)90012-6).

14. Blagodatski i S.A., B lagodatskaya E.V., Gorbenko A.Yu., Panikov N.S. Pochvovedenie, 1987, 4: 64-72.

15. Bates S.T., B erg-Lyons D., Caporaso J.G., Walters W.A., Knight R., Fie r e $\mathrm{r}$ N. Examining the global distribution of dominant archaeal populations in soil. ISME J., 2010, 5: 908-917 (doi: 10.1038/ismej.2010.171).

16. Caporaso J.G., Bittinger K., Bushman F.D., DeS ant is T.Z., Andersen G.L., $\mathrm{K} n \mathrm{ight}$ R. PyNAST: a flexible tool for aligning sequences to a template alignment. Bioinformatics, 2010, 26(2): 266-267 (doi: 10.1093/bioinformatics/btp636).

17. Vorob'ev N.I., Sviridova O.V., Kutuzova R.S. Metodicheskie rekomendatsii po ispol'zovaniyu graf-analiza $v$ issledovanii biosistem [Guidelines on the use of graph-analysis in the study of biological systems]. St. Petersburg, 2005.

18. Orlova O.V., Arkhip che nko I.A. V knige: Vysokoeffektivnye sistemy ispol'zovaniya organicheskikh udobrenii i vozobnovlyaemykh biologicheskikh resursov [In: High-effective use of organic fertilizers and renewable biological resources]. Vladimir, 2012: 99-106.

19. B a k i n a L.G. Rol' fraktsii gumusovykh veshchestv $v$ pochvenno-ekologicheskikh protsessakh. Avtoreferat doktorskoi dissertatsii [The role of humic fractions in soil ecological processes. DSci Thesis]. St. Petersburg, 2012.

20. S ix J., Frey S.D., Thi et R.K., B a t t e n K.M. Bacterial and fungal contributions to carbon sequestration in agroecosystems. Soil Science Society of America Journal, 2006, 70(2): 555569 (doi:10.2136/sssaj2004.0347). 